\title{
Cultivation mode research of practical application talents for optical engineering major
}

\section{Zhiying Liu}

Zhiying Liu, "Cultivation mode research of practical application talents for optical engineering major," Proc. SPIE 10452, 14th Conference on Education and Training in Optics and Photonics: ETOP 2017, 1045263 (16 August 2017); doi: 10.1117/12.2269905

Event: 14th Conference on Education and Training in Optics and Photonics, ETOP 2017, 2017, Hangzhou, China 


\title{
Cultivation Mode Research of Practical Application Talents for Optical Engineering Major
}

\author{
Zhiying Liu $^{* a}$ \\ ${ }^{a}$ School of opto-electronic engineering, Changchun University of Science and Technology, No 7089 \\ Weixing Road,Changchun, Jilin, CHINA 130022
}

\begin{abstract}
The requirements on science and technology graduates are more and higher with modern science progress and society market economy development. Because optical engineering major is with very long practicality, practice should be paid more attention from analysis of optical engineering major and students' foundation. To play role of practice to a large amount, the practice need be systemic and correlation. It should be combination of foundation and profundity. Modern foundation professional knowledge is studied with traditional optical concept and technology at the same time. Systemic regularity and correlation should be embodied in the contents. Start from basic geometrical optics concept, the optical parameter of optical instrument is analyzed, the optical module is built and ray tracing is completed during geometrical optics practice. With foundation of primary aberration calculation, the optical system is further designed and evaluated during optical design practice course. With the optical model and given instrument functions and requirements, the optical-mechanism is matched. The accuracy is calculated, analyzed and distributed in every motion segment. And the mechanism should guarantee the alignment and adjustment. The optical mechanism is designed during the instrument and element design practice. When the optical and mechanism drawings are completed, the system is ready to be fabricated. Students can complete grinding, polishing and coating process by themselves through optical fabricating practice. With the optical and mechanical elements, the system can be assembled and aligned during the thesis practice. With a set of correlated and logical practices, the students can acquire the whole process knowledge about optical instrument. All details are contained in every practice process. These practical experiences provide students working ability. They do not need much adaption anymore when they go to work after graduation. It is favorable to both student talents and employer.
\end{abstract}

Keywords: Optical engineering, Practice, Experience, Working ability

\section{INTRODUCTION}

Engineering education quality is a problem, especially lack of engineering graduates practical ability ${ }^{[1]}$. Although recently, we pay more attention to the practical teaching process in engineering education, the students' practical experience facility and situationality need to be further strengthened. The ribbon between theory and practice need to be tightened. And the relationship between theory and practice should be deal with we $11^{[2]}$.

It is shown in Mc. Kinsey Global Institute report of Oct.2005 that less than 10\% university graduates fit to international corporations; the reason is that the education is much more theoretical. And the practicaltrain ing is far from enough and powerful ${ }^{[3-4]}$. In contrast, the solve problem ability of European and US graduates are better. Many scholars relate innovation and entrepreneurship, with inventor and innovation, the new products is possible with new technology.

14th Conference on Education and Training in Optics and Photonics: ETOP 2017, edited by Xu Liu,

Xi-Cheng Zhang, Proc. of SPIE Vol. 10452, 1045263 • ( ) 2017 ICO, IEEE, OSA, SPIE

CCC code: $0277-786 \mathrm{X} / 17 / \$ 18 \cdot$ doi: $10.1117 / 12.2269905$ 
Entrepreneurs are those engineers, who know the development and product process, and be engineering leader generally ${ }^{[1-3]}$. With the university education innovation, what kind of talents to be cultivated becomes a good question. It has higher demands on output talents of university. The society needs newer combination talents, who have knowledge, ability and quality to make full use of knowledge and ability. The talents need to be foundation solid, knowledge broad, ability powerful and quality higher. Lab and exercise base are important base for higher technology talent of 21 century. It is important loader for quality education, orient the talent, knowledge and technology to economic construction , which has important function on innovation idea, exercise ability, analyze problem ability and solve problem ability ${ }^{[5]}$.

Consequently, put more efforts on the lab innovation to adapt to teaching reform and higher quality talent cultivation. It is necessary to study on how to implement quality education and cultivate talents with innovation spirit and ability. The practical process is the key factor for engineering quality education. And it is the important class for full quality education. Practical exerc ise e mbody very important role in engineering university and school, which includes cognition exercise, metal working exercise, production exercise, graduation exercise and graduation paper and design. Recently, series experiment, short essay and off-class technology activities are gradually increased.

Opto-electronic information science and engineering major is the noble major of Jilin Province, characteristic major of China. The innovation reforms need adjustment the courses combination and inheritance.

\section{INNOVATION PRACTICAL PROCESS CONSTRUCTIONS}

Practical teaching process is the important part in engineering quality education. It is effective to cultivate the engineering sense. The courses, foundation and second class construction are important guarantee conditions.

\subsection{Courses adjustment}

Through courses adjustment and reconstruction innovation, the practical process cultivation plan is reformed in detail. We built the relationship among optical design, optical fabrication, and optical structure design and instrument fabrication process. Students can have a whole cognition of research and production during optical instrument integration process. Comprehensive practical exercises are increased to prominent the research and development process of typical optical instrument. With optical design, structure design, instrument alignment and optical testing throughout the practical process, the innovation practical contents with courses correlate and systemic are embodied.

To inspire handmade and innovation of students, they have chance of make element and test system performance by themselves. All these efforts are for increase enthusiasm and interest of students. With these passion and reasonable practical exercise contents, the students' cultivation advantages will be the highlights .

\subsection{Foundation construction}

To imp rove the practical ability, only the campus resources are far from enough. So we need construct foundation out of campus to search Noble Corporation or factory to support our practical education process.

Changchun is the cradle of optics; we have many enterprises doing research and production related with optical element and instrument. So we built good bond with them. Students can have chance to exercise on the practical production line to experience the wonderful achievement sense. When encounter any problem about production, they can discuss with engineers or technicians. All these process give students broad knowledge, which cannot be acquired from class.

\subsection{Second class construction}

The innovation reform need not only exercise but also brains. It is important how to absorb and inspire students' brain storm. We start innovation credit plan to require 4credits at least during their teaching plan. But we do not set up detail courses about the innovation credits. They need find chance to get the innovation credits. We guide students through four-steps.

Firstly, we propose undergraduate excellent training (ESRTP). It is for junior or senior students. It aims at increasing fundamental research ability. The project system is applied. The project argument is organized by school. And students apply for project to school and tutor. Generally, the execution time is one year. Every project can get financial support from school to complete paper material collecting and thesis publication. If student can finish the project well, he can get 4 cred its of innovation, which shows that he is excellent. 
Secondly, we propose undergraduate innovation engineering opening lab (IELOP, engineering plan)

It is for sophomore, junior and senior students, who have or want to have certain engineering foundations. Through this plan, the engineering practical ability will be cultivated well. The opening lab plan is co-work out by research and teaching team. The plan includes students' capacity, training target and cultivation detail plan. It aims on cultivation engineering practical ability of students after experience in the opening lab plan. The execution time is one year. For prominent students in this plan, they can have further cultivation in the lab. For students who finish the innovation engineering opening lab plan, they will acquire 2 cred its in the innovation credits.

The third plan is undergraduate innovation entrepreneurship competition plan (IECTP, enterprising plan)

The innovation entrepreneurship project, varieties competition project, challenge cup and internet+ and so on are listed in practical process. These processes are managed by school. After sign up in these projects, students will enter innovation lab of school. The innovation lab provides working room, instrument device and instructors. If student finish the competition or innovation project, he can get 1 credit. If student can have honor of province, he can get 2 credits, and if student have honor of national, he can get 4 credits.

Another plan is the undergraduate fundamental training plan (IEBTP、Rookie plan)

The engineering fundamental software training is organized by school regularly. It includes optical design software (Zemax or CodeV), structure design software (Solid works or UG), structure analysis software (Patran). The students apply for it, and school arrange the training uniformly. After training, school will give test for students, if students can do the practical design project, we consider they are graduated. With qualified assessment, student can acquire $1 \mathrm{credit}$ in innovation credits.

\section{CONCLUSIONS}

No matter what kind of efforts we already made or making, we aim on practical engineering ability increasing. Through all these process, we indeed got better reward in undergraduate students' cultivation. More and more students are motive to participate second class project to exercise themselves. More and more passion students have to participate instructor's research work and find much fun during research process.

\section{REFERENCES}

[1] Li Jin. "The Curriculum Study of Entrepreneurial Engineering Talents," Huazhong University of Science \& Technology, Papers 2011.

[2] Carla Marie Bridges. "Entrepreneurship Education and Economic Development: Preparing the Workforce for the Twenty-first Century Economy,"Pro Quest Information and Learning Company, Papers 2008.

[3] Athreya, K. S. ,Kalthoff, Michael. "The Engineering Leadership Program: A Co-Curricular Leaning Environment by and for Student," Journal of STEM Education: Innovations and Research, Papers 13(4) : 70-74.

[4] Hansbonnet,Jacoquist,Dannhoogwater,Johanspaans,Carolinewehrmann. "Teaching sustainable entrepreneurship to engineering students: the case of Delft University of Technology,"European Journal of Engineering Education, Papers 31(2), 2006.

[5] DENG Ming, CHEN Wei-min, Guo Yong-cai. “ The exploration and practice of the innovative personnel training system of photoelectric information science and engineering," EDUCATION TEACHING FORUM ,Papers37(2016). 